\title{
PENGARUH KADAR KITIN DALAM PAKAN TERHADAP LAJU PERTUMBUHAN DAN KONSUMSI PAKAN HARIAN IKAN GURAMI Osphronemus gouramy LAC.
}

\author{
Anik M. Hariati', Hartati Kartikaningsih"), Dewa Gede Raka Wiadnya' \\ Yanti Suryanti"', dan Subagyo")
}

\begin{abstract}
ABSTRAK
Kitin merupakan suatu polimer rantai panjang dari N-asetil-D-glukosamin. Sumber pakan yang mengandung glukosamin dapat berfungsi sebagai pemacu pertumbuhan dan dapat meningkatkan daya cerna. Tujuan percobaan ini adalah untuk menghasilkan formulasi pakan yang difortifikasi kitin dari limbah pengolahan udang untuk memacu pertumbuhan ikan gurami. Benih ikan gurami yang digunakan ukuran $2,4 \pm 0,02 \mathrm{~g}$ ditebar dalam akuarium ukuran $100 \mathrm{~L}$ dengan kepadatan 50 ekor/akuarium. Perlakuan yang digunakan adalah perbedaan kadar kitin yang ditambahkan pada pakan yaitu $0 \% ; 4 \% ; 8 \% ; 12 \%$; dan $16 \%$. Setiap perlakuan terdiri atas tiga ulangan. Pemberian pakan sebesar $3 \%$ bobot ikan per hari dengan frekuensi dua kali per hari selama 30 hari. Pemberian kitin lebih dari $8 \%$ sudah tidak berpengaruh pada pertumbuhan harian ikan gurami. Penambahan kitin $8 \%$ ke dalam pakan dapat menghasilkan respon pertumbuhan dan pemanfaatan pakan lebih tinggi.
\end{abstract}

ABSTRACT: Effect of chitin in feed on the growth rate and daily feed consumption of gouramy. By: Anik M. Hariati, H. Kartikaningsih, Dewa Gede Raka Wiadnya, Yanti Suryanti, and Subagyo.

Chitin is a long chain polymer of N-Acetil-D-glocosamine. Feed source containing glucosamine may have a function as a growth stimulant and may increase the digestibility. The aim of this study was to produce formulation of feed fortified with chitin from shrimp processing waste to enhauce the growth of gouramy. Gouramy seed of $2.4 \mathrm{~g}$ were stocked in a $100 \mathrm{~L}$ aquarium with of density 50 fish/aquarium. Treatments of different chitin levels added to the feed were $0 \% ; 4 \% ; 8 \% ; 12 \%$; and $16 \%$. The experiment was carried out in three replications. Feed was given daily at $3 \%$ of biomass weight, twice a day for 30 days. The results showed that the chitin added at the level of higher than $8 \%$ had no significant effect on daily growth of gouramy. The $8 \%$ chitin in feed resulted in high growth response and higher feed efficiency.

KEYWORDS: chitin, gouramy, feed, growth rate.

\section{PENDAHULUAN}

Kulit udang mengandung senyawa kimia yang disebut kitin, yang merupakan salah satu jenis polimer alami (biopolimer) terbanyak ke dua setelah selulosa (Knorr, 1984). Meskipun sumber kitin di alam bermacam-macam, namum sampai saat ini sumber utama yang mudah diusahakan adalah cangkang udang-udangan yang secara ekonomis potensial seperti udang dan lobster. Keberadaan kitin dapat menunjang sejumlah besar bentuk kehidupan dari insekta, jamur, dan krustase. Dalam cangkang udang, kitin berikatan dengan protein, garam-garam anorganik seperti kalsium karbonat dan lipid termasuk pigmen-pigmen.

Sumber pakan yang mengandung glukosamin (polimer glukosa dan kitin) dapat berfungsi sebagai pemacu pertumbuhan pada udang. Hal ini terjadi terutama karena percepatan pertumbuhan dan metabolisme karbohidrat pada udang (Kanazawa et al., 1970; Kitabayashi et al., 1971; Clark et al., 1993 dan Fox, 1993). Selanjutnya Clark et al. (1993) menambahkan bahwa kitin antara 1\%-4\% pada sumber pakan akan meningkatkan daya cerna dan pertumbuhan udang. Hal ini memberikan indikas tentang kemampuan udang untuk menyerap dan menggunakan sumber pakan dari glukosamin Secara analog, glukosamin dari sumber kitin diharapkan juga mampu memacu pertumbuhan jenis organisme akuatik lainnya, termasuk ikan gurami (Osphronemus gouramy Lac)

Tujuan percobaan ini adalah untuk mengetahui formulasi pakan dan kadar kitin dalam pakan yang dapat memacu pertumbuhan ikan gurami.

Fakultas Perikanan. UNIBRAW

Peneliti pada Balai Penelitian Perikanan Air Tawar 


\section{BAHAN DAN METODE}

Sebelum pelaksanaan percobaan benih ikan gurami dilatih terhadap pakan yang akan diuji coba dalam akuarium selama satu minggu.

Benih ikan gurami berukuran $2,4 \pm 0,02 \mathrm{~g}$ ditebar dalam akuarium ukuran $100 \mathrm{~L}$ dengan kepadatan 50 ekor/akuarium. Perlakuan yang digunakan adalah perbedaan kadar kitin yang ditambahkan pada pakan, yaitu perlakuan $A=0 \% ; B=4 \% ; C=8 \% ; D=$ $12 \%$, dan $E=16 \%$. Setiap perlakuan terdiri atas tiga ulangan. Pemberian pakan sebesar $3 \%$ bobot biomassa ikan per hari dengan frekuensi pemberian tiga kali per hari Sebelum digunakan pakan uji dianalisis di laboratorium. Pada sore hari dilakukan koleksi sisa pakan pada setiap akuarium. Jumlah pakan yang tersisa (bobot kering) dalam akuarium secara tidak langsung menunjukkan tingkat konsumsi ikan terhadap pakan yang diberikan. Untuk mengetahui pertumbuhan ikan dilakukan penimbangan total ikan setiap 10 hari sekali dan penyesuaian jumlah pakan yang diberikan sesuai dengan pertambahan bobotnya. Bersama dengan itu dilakukan monitoring parameter kualitas air pada pagi hari pukul 07.00 yang meliputi suhu, DO, dan $\mathrm{pH}$. Percobaan ini dilaksanakan selama 30 hari.
Bahan dan komposisi pakan yang digunakan disajikan pada Tabel 1.

Analisis statistik hasil percobaan dilakukan dengan analisis ragam (Snedecor \& Cohran, 1991) Untuk mengetahui signifikasi dari perlakuan digunakan metode LSD pada taraf $5 \%$. Pengujian hubungan antara dosis kitin dalam pakan terhadap variabel yang diukur dilakukan dengan analisis regresi berdasarkan Snedecor \& Cohran (1991).

Parameter yang diukur

a. Laju pertumbuhan harian (SGR)

$$
S G R=\frac{\ln W_{t}-\ln W_{0}}{t} \times 100 \%
$$

b. Laju konsumsi pakan (R)

$$
R=\frac{F R}{B W g} \times 100 \%
$$

c. Konversi pakan (FCR)

$$
F C R=\frac{F}{W_{t}-W_{o}}
$$

\begin{tabular}{|c|c|c|c|c|c|}
\hline \multirow{2}{*}{$\begin{array}{l}\text { Bahan baku } \\
\text { Ingredient }\end{array}$} & \multicolumn{5}{|c|}{ Pakan (Diet) } \\
\hline & A & $\bar{B}$ & C & $\bar{D}$ & $\bar{E}$ \\
\hline Khitin (Chitin) & - & 4.0 & 8.0 & 12.0 & 16.0 \\
\hline Polietilen glikol (Polyethylene glycol) & 16.0 & 12.0 & 80 & 4.0 & \\
\hline Tepung ikan (Fish meal) & 32.0 & 32.0 & 32.0 & 32.0 & 32.0 \\
\hline Tepung kedelai (Soybean meal) & 31.0 & 31.0 & 31.0 & 31.0 & 31.0 \\
\hline Tepung darah (Blood meal) & 3.0 & 3.0 & 3.0 & 3.0 & 3.0 \\
\hline Tepung ubi kayu (Cassava meal) & 10.0 & 10.0 & 10.0 & 10.0 & 10.0 \\
\hline Minyak nabati (Vegetable oil) & 5.0 & 5.0 & 8.0 & 5.0 & 5.0 \\
\hline Vitamin premix (Vitamine $m i x)^{\star}$ & 1.5 & 1.5 & 1.5 & 1.5 & 1.5 \\
\hline $\mathrm{CMC}$ & 1.5 & 1.5 & 1.5 & 1.5 & 1.5 \\
\hline Total & 100.0 & 100.0 & 103.0 & 100.0 & 100.0 \\
\hline \multicolumn{6}{|l|}{ Komposisi (Composition) (\%) } \\
\hline Protein (Crude protein) & 35.0 & 35.0 & 35.0 & 35.0 & 35.0 \\
\hline Lemak (Fat) & 12.0 & 12.0 & 12.0 & 12.0 & 12.0 \\
\hline Energi (Energy) Kkal $/ \mathrm{kg}$ & 3.5 & 3.5 & 3.5 & 3.5 & 3.5 \\
\hline Karbohidrat (Carbohydrate) ${ }^{\star *}$ & 41.0 & 41.0 & 41.0 & 41.0 & 41.0 \\
\hline Abu (Ash) & 12.0 & 12.0 & 12.0 & 12.0 & 12.0 \\
\hline
\end{tabular}

Tabel 1. Formulasi dan komposisi pakan uji

Table 1. Formulation and compotition of tested diets.

* berdasarkan (based on) NRC (1983)

** karbohidrat $=100-($ protein+lemak+abu $) ;$ carbohydrate $=100-($ protein+fat+ash $)$ 
$\mathrm{W}_{0} \quad=$ Rata-rata bobot individu awal

W. = Rata-rata bobot individu thari

$\mathrm{FR} \quad=$ Feeding rate

$\mathrm{BWg}=$ Geometrik body weight

$\mathrm{F} \quad=$ Estimasi konsumsi pakan per individu selama 30 hari

\section{HASIL DAN BAHASAN}

Secara umum parameter kualitas air yang diukur selama penelitian berada pada kisaran baik untuk kehidupan ikan gurami. Suhu air berkisar antara $25,5^{\circ}-26,2^{\circ} \mathrm{C}$, oksigen terlarut $>3,5 \mathrm{mg} / \mathrm{L}$ dan $\mathrm{pH}$ berkisar 7,0-7,3

Hasil analisis ragam terhadap laju pertumbuhan harian menunjukkan bahwa pakan tanpa sumber kitin dan kandungan kitin 4\% menghasilkan pertumbuhan harian tidak berbeda nyata $(P>0,05)$. Sedangkan terhadap pemberian pakan dengan kandungan kitin
$8 \%-16 \%$ berbeda nyata $(P<0,05)$ dalam hal pertumbuhan ikan gurami (Tabel 2). Hal ini menunjukkan bahwa kitin cukup berperan dalam metabolisme karbohidrat pada tubuh ikan gurami.

Konsumsi pakan tanpa sumber kitin, paling tinggi 2,41 (Tabel 3), dan antara perlakuan A dan B tidak menunjukkan perbedaan $(P>0,05)$. Pada perlakuan $C$ dan $D$ laju konsumsi pakan menurun dan berbeda $(P<0,05)$ dengan perlakuan A dan B. Laju konsumsi terendah diperoleh pada pemberian kitin 16\% (perlakuan $E)$ dan berbeda nyata $(P<0,05)$ dengan perlakuan $A, B$, dan C

Semakin tinggi kandungan kitin dalam pakan maka tingkat konsumsi pakan semakin menurun. $\mathrm{Ha}$ ini terjadi karena efisiensi pemanfaatan pakan dari karbohidrat sebagai sumber energi, sehingga sumber energi dari protein dan lemak bisa disimpan sebagai cadangan pertumbuhan. Kondisi ini memberikan indikasi bahwa efisiensi pemanfaatan pakan pada

Tabel 2. Laju pertumbuhan harian gurami setiap perlakuan selama penelitian (30 hari)

Table 2. Daily growth rate of gouramy of each treatment during the experiment (30 days).

\begin{tabular}{|c|c|c|c|c|}
\hline \multirow{2}{*}{$\begin{array}{c}\text { Jumlah kitin dalam } \\
\text { pakan (\%) } \\
\text { Chitin content in } \\
\text { diet (\%) }\end{array}$} & \multicolumn{4}{|c|}{ Ulangan (Replication) } \\
\hline & 1 & 2 & 3 & $\begin{array}{l}\text { rata-rata } \\
\text { average }\end{array}$ \\
\hline 0 & 2.07 & 2.15 & 1.93 & $2.05 \pm 0.11^{a}$ \\
\hline 4 & 2.40 & 2.15 & 2.11 & $2.19 \pm 0.16^{a}$ \\
\hline 8 & 2.46 & 2.86 & 2.50 & $2.61 \pm 0.22^{b}$ \\
\hline 12 & 2.78 & 2.49 & 2.58 & $2.59 \pm 0.18^{\mathrm{b}}$ \\
\hline 16 & 2.53 & 2.61 & 2.59 & $2.54 \pm 0.14^{b}$ \\
\hline
\end{tabular}

Angka dalam kolom yang diikuti huruf superskrip yang sama tidak berbeda nyata Values in columns followed with the same superscript are not significantly $(P>5.0)$

Tabel 3. Laju konsumsi pakan harian gurami setiap perlakuan selama penelitian (30 hari).

Table 3. Daily consumption rate of gouramy of each treatment during the experiment (30 days)

\begin{tabular}{|c|c|c|c|c|}
\hline \multirow{2}{*}{$\begin{array}{c}\text { Jumlah kitin dalam } \\
\text { pakan (\%) } \\
\text { Chitin content in } \\
\text { diet }(\%)\end{array}$} & \multicolumn{4}{|c|}{ Ulangan (Replication) } \\
\hline & 1 & 2 & 3 & $\begin{array}{l}\text { rata-rata } \\
\text { average }\end{array}$ \\
\hline 0 & 2.43 & 2.45 & 2.31 & $2.41 \pm 0.04^{a}$ \\
\hline 4 & 2.40 & 2.37 & 2.40 & $2.39 \pm 0.02^{a}$ \\
\hline 6 & 2.35 & 2.31 & 2.28 & $2.31 \pm 0.05^{b}$ \\
\hline 12 & 2.29 & 2.22 & 2.27 & $2.26 \pm 0.04^{b c}$ \\
\hline 16 & 2.20 & 2.20 & 2.24 & $2.21 \pm 0.12^{c}$ \\
\hline
\end{tabular}

Angka dalam kolom yang diikuti huruf superskrip yang sama tidak berbeda nyata Values in columns followed with the same superscript are not significantly $(P>5.0)$ 
ikan yang menerima pakan tanpa kitin lebih rendah dibandingkan jika diberikan pakan dengan sumber kitin. Hal ini didukung dari hasil perhitungan konversi pakan yaitu semakin tinggi kandungan kitin yang diberikan maka konversi pakan semakin menurun (Tabel 4). Konversi pakan pada perlakuan A dan B tidak berbeda nyata $(P>0,05)$. Konversi pakan pada perlakuan C, D dan E semakin menurun dan di antara ketiga perlakuan tersebut tidak berbeda $(P>0,05)$, namun berbeda terhadap perlakuan $A$ dan $B$.
Departemen Pendidikan dan Kebudayaan yang telah memberikan kesempatan dan dana untuk melaksanakan penelitian ini.

\section{DAFTAR PUSTAKA}

Clark, D.J., A.L. Kawrence and D.H.D. Swakon 1993 Apparent chitin digestibility in penaeid shrimp. Aquaculture, 109:51-57

\begin{tabular}{|c|c|c|c|c|}
\hline \multirow{2}{*}{$\begin{array}{c}\text { Jumlah kitin dalam } \\
\text { pakan (\%) } \\
\text { Chitin content in } \\
\text { diet }(\%)\end{array}$} & \multicolumn{4}{|c|}{ Ulangan (Replication) } \\
\hline & 1 & 2 & 3 & $\begin{array}{l}\text { rata-rata } \\
\text { average }\end{array}$ \\
\hline 0 & 2.43 & 2.45 & 2.31 & $1.16 \pm 0.06^{a}$ \\
\hline 4 & 2.40 & 2.37 & 2.40 & $1.07 \pm 0.02^{a}$ \\
\hline 6 & 2.35 & 2.31 & 2.28 & $0.88 \pm 0.07^{b}$ \\
\hline 12 & 2.29 & 2.22 & 2.27 & $0.88 \pm 0.05^{b}$ \\
\hline 16 & 2.20 & 2.20 & 2.24 & $0.84 \pm 0$ \\
\hline
\end{tabular}

Angka dalam kolom yang diikuti huruf superskrip yang sama tidak berbeda nyata Values in columns followed with the same superscript are not significantly $(P>5.0)$

Dari hasil tersebut dapat diduga bahwa kitin dapat membantu dalam mencerna pakan sehingga menjadi nutrien yang mudah diserap oleh ikan. Diduga bahwa kitin berperan dalam metabolisme karbohidrat pada ikan gurami. Hasil penguraian kitin berupa $\mathrm{N}$-asetilglukosamin berfungsi sebagai pemacu pertumbuhan (Lynn, 1990; Spindler-Bath et al., 1990). Dengan meningkatnya daya cerna karbohidrat dan lemak menyebabkan kemungkinan adanya penukaran penggunaan protein sebagai sumber energi, pengurangan proses termogenesis oleh pakan, menurunnya kebutuhan kalori untuk produksi dan ekskresi nitrogen (Machiels \& Henken, 1985; Machiels, 1987).

\section{KESIMPULAN}

Penambahan kitin ke dalam pakan ikan dapat mempengaruhi respon pertumbuhan dan efisiensi pemanfaatan pakannya. Penambahan kitin ke dalam pakan sebesar 8,0\% dapat menghasilkan respon pertumbuhan dan pemanfaatan pakan yang lebih tinggi.

\section{UCAPAN TERIMA KASIH}

Tim Peneliti menyampaikan terima kasin kepada Agricultural Research Management Project (ARMPII) dan Direktorat Jenderal Pendidikan Tinggi (DIKTI)
Fox, C.J. 1993. The effect of dietary chitin on growth. survival and chitinase levels in the digestive gland of juvenile Penaeus monodon. Aquaculture, 109:39-49

Kanazawa, A., M. Shimaya, M. Kawasaki and K Kashiwada. 1970. Nutritional requirements of prawn, I. feeding on artificial diet. Bull. Jap. Soc. Sci. Fish. 36:949-954

Kitabayashi, K., H. Kurata., K. Shudo, K. Nakamura and S. Ishikawa. 1971. Studies on formula feed for kuruma prawn. I. On relationship among glucosamine phosphorus and calsium. Bull. Tokai Reg. Fish. Res. Lab 65:91-207.

Knorr, D. 1982. Functional properties of chitin and chitosan. J. Food Sci. and Technol. Vol. 47:593

Lynn, K.R. 1990. Chitinases and Chitobiases from the American lobster (Homarus americanus). Comp. Biochem. Physiol., 96B:761-766.

Machiels, M. and A. Henken. 1985. Growth rate, feed utilization and energy metabolism of the African catfish (Clarias gariepinus), as affected by dietary protein and energy content. Aquaculture 44:271-284

Machiels, M.A.M. 1987. A. Dynamic simulation model for growth of the African catfish, Clarias gariepinus (Burchell 1822): IV. The effect of feed formulation on growth and feed utilization. Aquaculture, 64:305-323.

Muzzarelli, R.A.A. 1977. Chitin. Pergamon Press. New York.

NRC. 1983. Nutrient Requirement of Warm Water Fishes. Washington D.C., National Academy of Sciences. 
Snedecor, G. and W. Cochran, 1991. Statistical methods, 8th edition, lowa State University Press, lowa, USA. $499 \mathrm{pp}$

Suhadi, U. Santoso, S. Angrahini, Nurcahyanto. 1993. Buku Monograf Khitin dan Khitosan. PAU. Pangan dan Gizi. UGM, Yogyakarta
Spindler-Bath. M., A. Van Wormhoundt, \& K.D. Spindler 1990. Chitinolytic enzymesin the integument and midgut-gland of the shrimp Palaemon serratus during the moulting cycle. Mar, Biol., 106:49-52. 